\title{
AKTUÁLNY OBRAZ ČESKA AKO TURISTICKEJ DESTINÁCIE VYTVORENÝ VYSOKOŠKOLSKÝMI ŠTUDENTMI - POTENCIÁLNYMI NÁVŠTEVNÍKMI ZO SLOVENSKA
}

\author{
Rastislav Cákoci, Ladislav Tolmáči* \\ * Univerzita Komenského v Bratislave, Prírodovedecká fakulta, Katedra regionálnej geografie, ochrany \\ a plánovania krajiny, Ilkovičova 6,84215 Bratislava, rastislav.cakoci@uniba.sk, ladislav.tolmaci@uniba.sk
}

\begin{abstract}
Current destination image of Czechia created by university students - potential visitors from Slovakia

Tourism destination image is one of the represented relevant elements of tourism development. It refers to the visitor's perception of the country in all its complexity. Tourism destination image should be useful in the process of a target marketing strategy creation. This article focuses on comparing official statistics data about the spatial distribution of tourists from Slovakia in Czechia with data from the empirical research of tourism destination image evaluation and analysis deviations between the real situation and the destination image as a result of research. To evaluate the destination image, the authors used a part of the AQITI method. Respondents (university students) were asked to simulate and create a travel itinerary to Czechia. In the research task the city of Prague was omitted as a tourism attraction due to its overwhelming popularity in comparison with the rest of the Czech regions. In the created destination image of Czechia, city tourism dominated as main form. Landscape activities like hiking and paddle tourism activities are next in order. On the other hand, research uncovered places and activities in destination image which may remain unknown for respondents. Here there should be place for local DMO's in Czechia for destination image stimulating activities.
\end{abstract}

Key words: tourism destination image, tourists, AQITI, method, Czechia, Slovakia

\section{ÚVOD}

Problematika vzt’ahu obrazu územia a cestovného ruchu sa spája s termínom obraz turistickej destinácie - angl. tourism destination image (TDI). Tento vzt'ah sa odvíja od prvopočiatkov vnímania obrazu ako individuálneho mentálneho konštruktu vytvoreného jednotlivcom (Hunt 1975), cez priestorový (regionálny) prístup, kde TDI predstavuje celkovú impresiu miesta (Pan a Li 2011). Aktuálne sa do problematiky zahŕňa aj časová dimenzia a obraz regiónu sa chápe ako dynamický prvok vznikajúci zo spracovania informácií z rozmanitých zdrojov v priebehu času (Choi 2007).

Vychádzajúc z konceptu obrazu regiónu cestovného ruchu ako mentálneho konštruktu je možné ho rozdelit' na dva základné typy. Obraz pred návštevou regiónu (pre-visit image) a obraz po návšteve, zahrnujúci osobnú skúsenost' (post-visit image). Pri obidvoch typoch obrazu dochádza k jeho odlišnému formovaniu (Beerli a Martín 2004) a má aj odlišný interpretačný význam (Govers et al. 2007).

Obraz ako predmet výskumu sa viaže na rôznu mierku objektu výskumu - od mesta, cez región, krajinu či celý svetadiel. Obraz mesta vychádza hlavne z Lynchovho konceptu obrazu mesta (Lynch 1960), počnúc prípadovými štúdiami tvorby 
mentálnych máp (napr. Gould a White 1986 a Gregorová 2008) až po percepčnú analýzu návštevníkov mesta (Ot’ahel' et al. 2018). V sumarizačnej práci venujúcej sa analýzam TDI prevládalo hodnotenie obrazu krajiny ako najčastejšej mierky (Pike 2002).

Ciel' príspevku má dve roviny. Prvou je na základe dostupných štatistických ukazovatel'ov charakterizovat' dôležitost' návštevníkov zo Slovenska pre cestovný ruch Česka a ich správanie. Druhou rovinou je predstavenie priestorového rozmiestnenia atraktívnych turistických lokalít pomocou tvorby aktuálneho percepčného obrazu Česka ako letnej turistickej destinácie, platného pre skupinu potenciálnych návštevníkov z radov vysokoškolských študentov. Účelovo je z tohto obrazu vynechané hlavné mesto Praha. Zároveň na základe vzniknutého obrazu môžeme odhalit' a pomenovat' priestorové deformácie medzi štatisticky evidovanou realitou ubytovaných návštevníkov zo Slovenska a plánovanými návštevami. Príspevok má tiež ambíciu zhodnotit' výber informačných zdrojov, s ktorými respondenti pracovali a ktoré sa spolupodiel'ali na tvorbe obrazu.

Pre cielený marketing zameraný na potenciálnych návštevníkov, prípadne jeho optimalizáciu, je vel'mi nápomocná analýza a hodnotenie obrazu turistickej destinácie. Baloglu a McCleary (1999, p. 870) definujú problematiku nasledovne: „Obraz regiónu cestovného ruchu je subjektívny mentálny konštrukt pozostávajúci z individuálnej reprezentácie vedomostí, pocitov a globálnych predstáv o regióne cestovného ruchu“. Z pohl'adu potenciálneho návštevníka predstavuje obraz prvú fázu v rozhodovacom procese pri výbere ciel'ovej destinácie. S takto formulovaným postulátom sa stotožnilo viacero autorov skúmajúcich problematiku obrazu destinácie cestovného ruchu od jej počiatku (Hunt 1975, Goodrich 1978, Mayo a Jarvis 1981, Chon 1990, Baloglu a McCleary 1999, Leisen 2001, Echtner a Ritchie 2003 a Pike 2009). Analýze obrazu destinácií cestovného ruchu sa venujú viaceré metodické prístupy. Ked’že sa internet stal dominantným médiom na získavanie informácií a tiež plánovanie dovolenky z pohl'adu spotrebitel'a a zároveň efektívnym marketingovým nástrojom z pohl'adu destinačného manažmentu (Law et al. 2010), príspevok využíva na hodnotenie obrazu Česka vytvoreného potencionálnymi slovenskými návštevníkmi metódu AQITI (Cákoci 2008, 2009 a 2015), ktorá hodnotí obraz regiónu cestovného ruchu skonštruovaný z internetových zdrojov.

\section{SLOVENSKÍ TURISTI V ČESKU}

Cestovný ruch v Česku sa v roku 2014 podiel'al 2,8 percentami na tvorbe HDP a 4,41 percentami na zamestnanosti (Ministerstvo pro místní rozvoj ČR 2018). Podstatnú čast' výkonov pri aktívnom cestovnom ruchu však vytvára hlavné mesto Praha. V roku 2017 bolo až 38,2 \% zo všetkých návštevníkov ubytovaných v Prahe (Český statistický úřad 2018). Praha patrí k dominantným turistickým destináciám príjazdového cestovného ruchu v Českej republike (Vystoupil et al. 2011). Táto tendencia je viditel'ná aj pri návštevníkoch pochádzajúcich zo Slovenska, ked' až 42,1 \% návštevníkov v roku 2017 bolo ubytovaných v Prahe. Medzi rokmi 2012 2017 sa pohyboval podiel Slovákov ubytovaných v hlavnom meste medzi 41,7 až 44,4 \% zo všetkých ubytovaných Slovákov v Česku (Český statistický úr̆ad 2018).

Medzi rokmi 2015 - 2017 sa radili návštevníci ubytovaní v hromadných ubytovacích zariadeniach (HUZ) pochádzajúci zo Slovenska na druhé miesto (za návštevníkov z Nemecka) s 3,4-percentným podielom (688 490 abs.) zo všetkých ubytovaných návštevníkov v HUZ za rok 2017 (6,8-percentný podiel z množiny zahra- 
ničných ubytovaných návštevníkov v HUZ za rok 2017). Dlhodobý vývoj ukazuje narastajúci počet aj podiel návštevníkov zo Slovenska, čo neustále zvyšuje ich dôležitost' pre cestovný ruch Česka (obr. 1). Viditel'ne sa skracuje priemerný počet prenocovaní, čo však nie je znepokojujúce, ked’že vývoj len kopíruje globálny trend (Martinéz-Garcia a Raya 2008). V roku 2017 však návštevníci zo Slovenska realizovali kratšie pobyty $(2,0$ prenocovaní) $\mathrm{v}$ porovnaní $\mathrm{s}$ priemerom $\mathrm{v}$ celom Česku (2,7 prenocovaní).

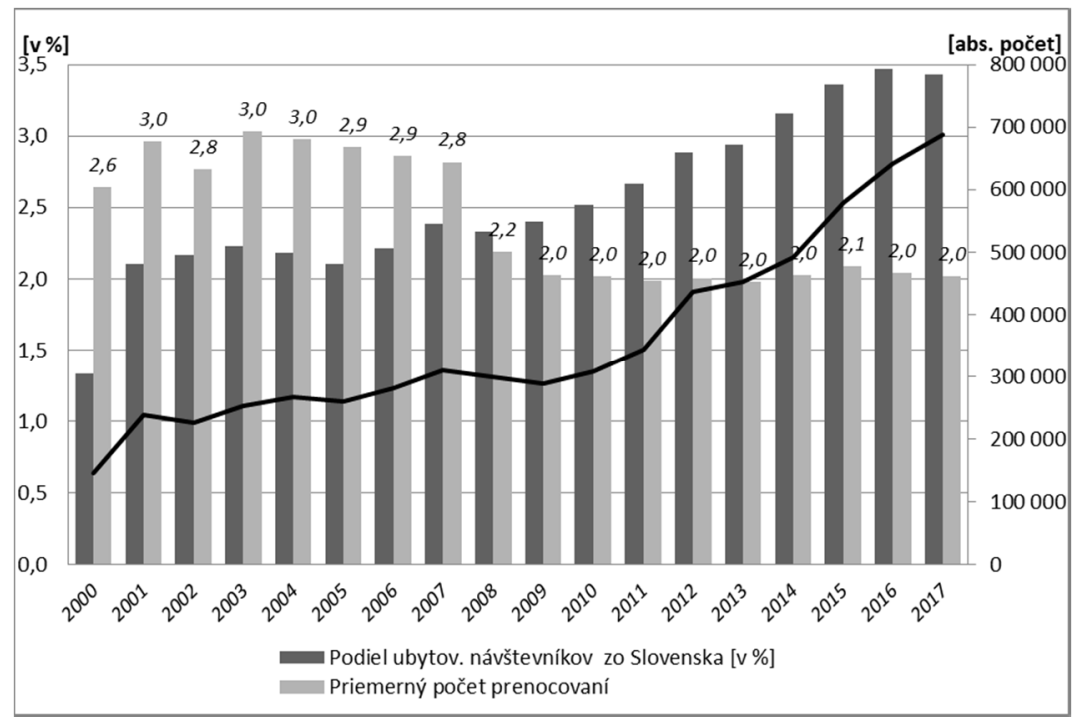

Obr. 1. Vývoj ubytovaných návštevníkov zo Slovenska v HUZ v rokoch $2000-2017$ v Česku

Zdroj: Český štatistický úr̆ad (2018), vlastné spracovanie.

Z priestorového hl'adiska najviac návštevníkov pochádzajúcich zo Slovenska navštívi spomínanú Prahu s 289523 ubytovanými návštevníkmi v HUZ za rok 2017. Na druhom mieste bol v roku 2017 Juhomoravský kraj s počtom 111845 ubytovaných, čo tvorilo 16,2-percentný podiel zo všetkých ubytovaných návštevníkov zo Slovenska. Dalšie dva hraničné kraje Zlínsky (43 266) a Moravskosliezsky (41 613) zaznamenali 6,3-, resp. 6-percentný podiel. Naopak, najnižší počet ubytovaných návštevníkov zo Slovenska bol v roku 2017 zaznamenaný v Libereckom (11 539), Ústeckom (14 124), Plzenskom (14 157) a Karlovarskom (15 885) kraji. Pri pohl'ade na podiel ubytovaných návštevníkov v HUZ zo Slovenska na celkovej návštevnosti v jednotlivých krajoch, teda na ukazovatel', ktorý hovorí o význame a dôležitosti návštevníkov zo Slovenska (obr. 2), je evidentný vplyv polohy. V krajoch hraničiacich so Slovenskom sa podiel zvyšuje. Najdôležitejšiu pozíciu majú v Zlínskom a Juhomoravskom s 6-, resp. 5,9-percentným podielom zo všetkých návštevníkov. V Zlínskom kraji predstavujú Slováci takmer 36 \% zo všetkých zahraničných ubytovaných návštevníkov v HUZ. Významnú pozíciu dosahujú aj v Moravskosliezskom kraji so 4,6-percentným podielom zo všetkých návštevníkoch a s 21,7-percentným podielom zo zahraničných ubytovaných návštevníkoch v HUZ. Celkovo v šiestich krajoch - Juhomoravskom, Zlínskom, Moravskosliez- 
skom, Olomouckom, na Vysočine a Pardubickom predstavujú Slováci najpočetnejších zahraničných návštevníkov.

Pri pohl'ade na vývoj návštevnosti počas roku 2017 možno konštatovat', že hlavná sezóna sa viaže na letné mesiace júl a august, avšak výrazne vyprofilovanú letnú preferenciu zaznamenávajú len Juhočeský, Zlínsky, Karlovarský, Liberecký a Královohradecký kraj. Počas letných mesiacov sa tiež mierne zvyšuje priemerná dížka pobytu. V ostatných krajoch mesiace júl a august nedosahujú výraznú dominanciu. Sezóna je rovnomernejšie rozložená od apríla (čiastočne marca) až do novembra. Na porovnanie podiel českých návštevníkov v roku 2017 v Juhomoravskom kraji v júli a auguste predstavoval $29 \%$ z celého roka, zatial' čo medzi návštevníkmi zo Slovenska tvorili letné mesiace len 21,9 \%. Podiel návštevníkov z Pol'ska, ako druhých najpočetnejší zahraničných návštevníkov v Juhomoravskom kraji v dvoch letných mesiacoch, prestavoval až 30,1 \% z celého roku. Fakt, že návštevník zo Slovenska si vie nájst' cestu do Českej republiky v širšej sezóne, nielen v júli a auguste, by mal byt' kl'účový pri činnosti organizácií destinačného manažmentu.

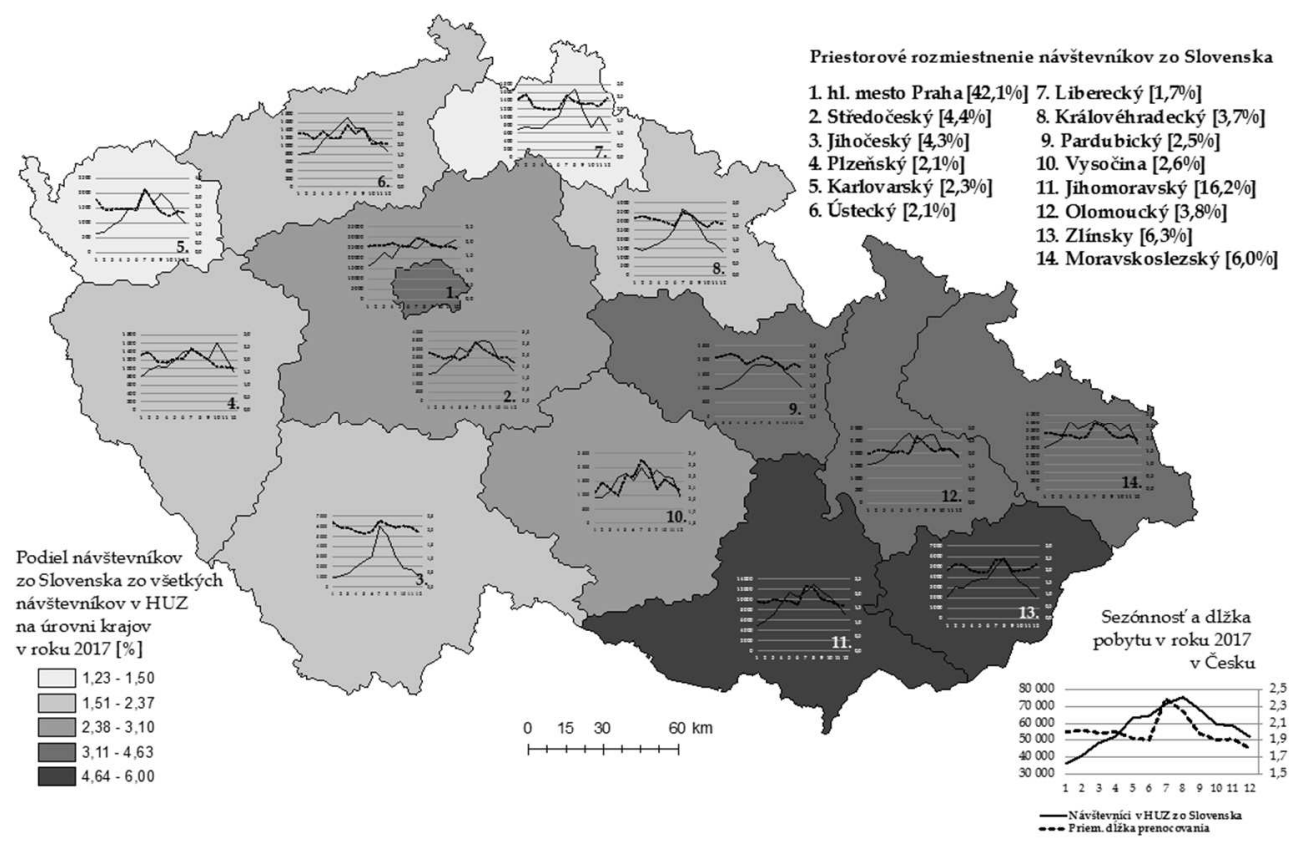

Obr.2. Návštevníci v Česku pôvodom zo Slovenska v HUZ v roku 2017 Zdroj: Český štatistický úřad (2018) a vlastné spracovanie.

Výskum Českej centrály cestovného ruchu - CzechTourism (CzechTourism 2017) realizovaný od apríla 2015 do decembra 2016 na hraničných prechodoch sa okrem iného venoval jednodňovým návštevníkom Česka. Odhad počtu jednodňových návštevníkov, resp. návštev zo Slovenska, sa pohybuje na úrovni 14 \% zo všetkých jednodňových návštev Česka, čo v odhadovanom prepočte predstavuje približne 2274000 jednotlivých návštev. V súbore všetkých jednodňových náv- 
števníkov takmer dve tretiny navštívi Česko minimálne jedenkrát do mesiaca a až $80 \%$ jednodňových návštevníkov uvádza ako hlavný dôvod nákupy. Táto početná skupina návštevníkov je viazaná na cezhraničné väzby medzi Českom a Slovenskom. Ide o vel'mi intenzívne migračné toky priestorovo sa viažuce na tri hraničné kraje Juhomoravský, Zlínsky a Moravskosliezsky s najintenzívnejšími väzbami na mestá Hodonín a Břeclav. Zo strany slovenských návštevníkov sa však dá predpokladat' zvýšený záujem aj o časovo dostupné turistické atrakcie v pohraničí v spomenutých troch krajoch, čo bezpochyby zvyšuje podiel a význam návštevníkov zo Slovenska v týchto lokalitách.

Návštevníci zo Slovenska patria vôbec k najspokojnejším návštevníkom Česka a majú aj najlepší prehl'ad o možných turistických ciel'och (CzechTourism 2014). Podl'a prieskumu Ceskej centrály cestovného ruchu - CzechTourism si Slováci spájajú Česko s dlhoročnou históriou, kultúrnymi pamiatkami, dobrou dopravnou a cenovou dostupnost'ou. Podl'a interného respondentského prieskumu (CzechTourism 2010), zameraného na hodnotenie obrazu, respektíve asociatívnych prvkov obrazu Česka medzi vybranými návštevníkmi, dominovala medzi Slovákmi Praha. Až $49 \%$ potenciálnych návštevníkov a 46 \% návštevníkov s osobnou skúsenost’ou zo zúčastnených na výskume si vybavili v spojitosti s Českom práve Prahu. Vo všeobecnosti je obraz oboch skupín pozitívny, no hoci to výsledky výskumu nekonštatujú, obraz je do istej miery nekonkrétny, resp. vyhodnotené prvky obrazu sú málo špecifické. Potenciálni návštevníci si Česko asociujú s termínmi susedný štát, pamiatky, pivo, príbuzní/kamaráti, krajina/hory a návštevníci s pojmami pamiatky, susedný štát, pivo, krajina/hory či príroda. Slabá špecifikácia sa dá pripísat' zhlukovaniu odpovedí do tematických množín.

\section{KRÁTKODOBÝ VÝSKUM (METÓDA AQITI)}

Metóda AQITI (A ccessibility and Quality of Information about Tourism on the Internet) komplexne hodnotí dostupnost' a kvalitu informácií o hodnotenom regióne cestovného ruchu na internete. Predstavuje viacúrovňovú výskumnú metódu, pričom kombinuje kvantitatívne aj kvalitatívne postupy (Cákoci 2008, 2009 a 2015). $\mathrm{Na}$ vytvorenie obrazu Česka bola využitá parciálna čast' metódy - krátkodobý nárazový výskum na hodnotenie virtuálneho obrazu. Krátkodobý výskum s využitím respondentov zist'uje atraktívnost' skúmaného regiónu pre potenciálnych návštevníkov. Metóda AQITI bol aplikačne využitá v rôznych regiónoch (Hanusová 2012, Jahnátková 2013, Konrádová 2013 a Jamborová 2018).

Respondenti majú ciel'ový región cestovného ruchu dopredu určený a práve v ňom si majú naplánovat' l'ubovol'ne dlhý pobyt v určenej sezóne. Výskum teda nesleduje príčiny a dôvody jeho výberu a taktiež sa nezaujíma o konkrétnu aktivitu. Ciel'om nárazového výskumu je sledovanie vnútroregionálnej atraktívnosti a dostupnosti miest, aktivít a atrakcií cestovného ruchu. Zameriava sa na schopnost' regiónu oslovit', zabavit' a udržat' návštevníka priamo v skúmanom regióne. Respondenti v úlohe potenciálneho návštevníka určia aký dlhý čas si dokážu za pomoci internetových stránok plnohodnotne naplánovat', vrátane náčrtu aktivít počas jednotlivých dní. Krátkodobý výskum sa realizuje v stanovenom obmedzenom čase. Z dôvodu zvýšenia výpovednej hodnoty výskumu a dôrazu na ostatné regióny Česka bola Praha zo zadania účelovo vyňatá. Na základe predošlých výskumov vyhotovených Českou centrálou cestovného ruchu - CzechTourism (2010 a 2014) bola vysoká atraktivita hlavného mesta pravdepodobná. Účelom realizovaného vý- 
skumu naopak bolo dat' dôraz na atraktivitu ostatných častí Česka a priestorovú interpretáciu.

Výskum bol realizovaný v septembri 2016 medzi študentmi Prírodovedeckej fakulty Univerzity Komenského v Bratislave. Z výskumu vzišlo od respondentov 66 itinerárov vhodných na vyhodnotenie. Platnost' obrazu je úzko vymedzená vysokoškolskými študentmi vo vekovej kategórií 19 - 24 rokov, aktuálnej pre rok 2016. Každý z respondentov pomocou počítača s pripojením na internet spracoval nasledujúce zadanie: ,V časovom limite 45 minút si individuálne naplánujte dovolenku v letnom období v Českej republike mimo návštevy Prahy. Dlžka pobytu je l'ubovol'ná a závisí len od vašej spokojnosti. Počas plánovania dovolenky si vytvorte rozvrh na jednotlivé dni, ktorý napíšte do dokumentu. Rozvrh bude pozostávat' z jednotlivých aktivít, ktoré by ste chceli počas dovolenky realizovat' a miest, lokalít, regiónov, ktoré by ste chceli vidiet' a navštívit'،.

Hodnotenie virtuálneho obrazu regiónu cestovného ruchu je podmienené vzt'ahom medzi regiónom, ktorého obraz vytvárame a obraz vytvárajúcou skupinou l'udí (Cákoci 2015). Pre konštrukciu virtuálneho obrazu je dôležitý rozdiel medzi návštevníkmi s osobnou skúsenost'ou alebo bez nej (Baloglu a McCleary 1999) a tiež kultúrny vplyv, pod ktorým sa vytvára (Leisen 2001, Davidson a Yu 2005 a Kozak 2007). Vzniknutý virtuálny obraz Česka má obmedzenú platnost' pre mladých l'udí zo Slovenska (v užšom chápaní vysokoškolských študentov) preferujúcich individuálny cestovný ruch a v tomto kontexte treba vnímat' aj všetky výstupy. Všetky hodnotené itineráre splnili podmienku, že respondent nemá osobnú skúsenost' s dovolenkovým pobytom v Česku. Krátkodobá návšteva (Praha, Brno a pod.) nebola limitujúca pre zaradenie itinerára do hodnotenia vzniknutého virtuálneho obrazu.

\section{VÝSLEDKY A DISKUSIA}

Návštevníci zo Slovenska vnímajú Českú republiku ako dostupnú a Slovensku podobnú krajinu, kam by sa vybrali realizovat' širokú škálu činností od mestskej turistiky, spoločenského života až po gurmánske návštevy a odpočinok (CzechTourism 2014). Doteraz realizované výskumy sa nezaoberali priestorovým aspektom problematiky. Práve analýza priestorových preferencií turistických atraktivít je výstupom krátkodobého výskumu metódy AQITI. Časové nastavenie výskumu na jeseň 2016 s plánovaním pobytu na leto 2017 poskytuje možnost' konfrontácie dížky naplánovaného pobytu s reálnymi hodnotami ubytovaných návštevníkov v HUZ v lete 2017. Respondenti si naplánovali 3,5 prenocovaní, čo je v porovnaní so štatistickou realitou viac. V roku 2017 v mesiacoch júl a august realizovali Slováci v priemere 2,4 prenocovania v HUZ v Českej republike mimo Prahu (Český statistický úřad 2018). Z tohto pohl'adu sa vzniknutý obraz z typologického hl'adiska metódy AQITI radí do kategórie pozitívne predimenzovaný. Tento typ virtuálneho obrazu sa vyznačuje výrazne atraktívnou prezentáciu na internete a výbornou dostupnost'ou informácií. Môže však so sebou niest' isté riziko sklamania návštevníka počas reálnej návštevy v prípade nenaplnených očakávaní. Pre zaujímavost' počet prenocovaní domácich (českých) návštevníkov v HUZ mimo hlavné mesto v mesiacoch júl a august 2017 predstavoval v priemere 3,3 prenocovania (Český statistický úrad 2018). V prípade tohto počtu prenocovaní by sa typ obrazu zmenil na vyvážený virtuálny obraz, ktorý reálne zodpovedá ponuke regiónu. 
Obr. 3 vizualizuje výsledky výskumu na respondentoch a vytvára virtuálny obraz Česka v súvislosti s atraktívnost'ou konkrétnych lokalít platný pre vysokoškolských študentov. Z realizovaného výskumu je viditel'ný prevládajúci mestský cestovný ruch. Ako najatraktívnejšie lokality sa ukázali Karlove Vary a Brno s 30, resp. 28 jednotlivými návštevami naplánovanými respondentmi $(45 \%$, resp. $42 \%$ zo všetkých respondentov). Nasledovali mestá Plzeň, České Budějovice, Český Krumlov, Ostrava a tiež Olomouc, Hradec Králové, Znojmo a Kroměříž. Z areálov hradov a zámkov dominoval Karlštejn a tiež Lednicko-valtický areál. Čast' naplánovaných aktivít v Česku sa viazala na pobyt v prírode, pešiu a vodnú turistiku. V sedemnástich itinerároch sa objavil Národný park Šumava a v trinástich Krkonošský národný park. Ten sa viazal na čast' lokalizovanú na území Královohradeckého kraja špeciálne so zameraním na Špindlerův Mlýn a Sněžku. V menšej miere boli v itinerároch zahrnuté národné parky Podyjí a České Švýčarsko, ako aj na susedná Chránená krajinná oblast' Lábske pískovce, či Krušné hory. Zvýšený záujem sa prejavil aj o lokalitu Moravský kras a priepast' Macocha. Výsledky výskumu sú do istej miery v rozpore so zisteniami rozsiahleho výskumu na českých a moravských respondentoch (Šifta a Chromý 2014), kde autori konštatujú nižšiu mieru identifikácie prírodných symbolov v regióne severozápadných Čiiech. Pri detailnejšom pohl'ade na percepčný obraz vytvorený respondentmi zo Slovenska možno konštatovat', že práve prírodné prvky sú pre Ústecký kraj charakteristické. Zaujímavost'ou je, že autori si všimli nižšiu mieru identifikácie prírodných symbolov v Ústeckom kraji pri respondentoch z Čiech a vyššiu pri respondentoch z Moravy. $\mathrm{V}$ nadväznosti na túto skutočnost' je možné spomenutý rozpor nahradit' vol'ne formulovaným postrehom, čím východnejšie je lokalizovaný respondent, tým vyššia je atraktívnost' prírodných lokalít v Ústeckom kraji. Pomerne častou aktivitou v plánovaných itinerároch bolo splavovanie. Splav na rieke Morava sa viazal len na územie Juhomoravského kraja, pričom atraktívne úseky v Olomouckom kraji ostali nepovšimnuté. Splav na rieke Vltava rovnomerne vystupoval aj v Juhočeskom aj Stredočeskom kraji. Poslednou spomenutou riekou bola Sázava. Ostatné vodné toky ostali nepovšimnuté.

Najcennejším výstupom výskumu sú slabo viditel'né, respektíve úplne opomenuté miesta, atrakcie či aktivity. Virtuálnemu obrazu atraktívnosti lokalít cestovného ruchu vel'mi chýbali aktivity viažuce sa na vidiecky cestovný ruch, pamiatky l'udovej architektúry a čiastočne vinársky cestovný ruch v Stredočeskom kraji (Vystoupil et al. 2006). Celkovo sa respondenti neprepracovali k žiadnym informáciám o kultúrno-hudobných podujatiach. Nevyskytla sa ani jediná zmienka o organizovaných podujatiach, hoci počas letnej sezóny bývajú dôležitou súčast'ou kultúrneho programu vo všetkých sídlach bez rozdielu vel'kosti. Na základe realizovaného výskumu by bolo vhodné odporučit' zainteresovaným aktérom zamerat' sa pri internetovej prezentácii na propagáciu vlastných podujatí, ako aj na gastronómiu či remeselnú výrobu. Tieto prvky boli v itinerároch značne poddimenzované. Pivo ako dôležitý symbol, no aj produkt turistického záujmu, sa spomínalo len na úrovni tradičných vel'kých aktérov, akými sú Plzeň či České Budějovice.

Výskum ukázal aj značný rozdiel v povedomí o vínnej turistike. Zatial' čo vinárska oblast' Morava lákala, respektíve doplńnala viaceré itineráre v tomto regióne (okrem Slováckej podoblasti), tak vinárska oblast' Čiech ostala úplne nepovšimnutá. Vo vytvorenom virtuálnom obraze absentovali aj viaceré lokality zapísané na zozname svetového dedičstva UNESCO. 


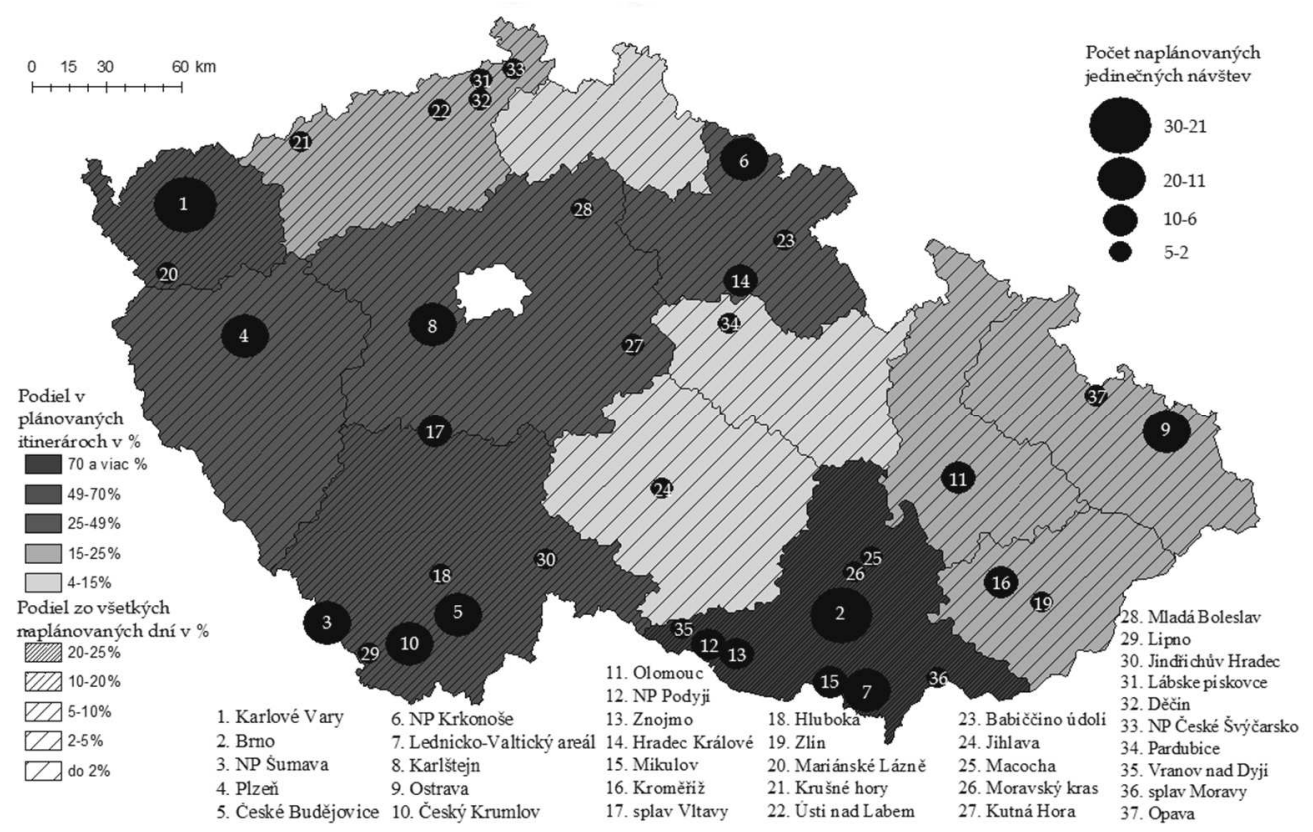

Obr. 3. Obraz Česka vytvorený potenciálnymi návštevníkmi zo Slovenska v roku 2016

Zdroj: vlastné spracovanie.

Zaujímavé porovnanie poskytuje tab. 1, ktorá vytvára poradie reálnej návštevnosti a plánovaných itinerárov na úrovni krajov. Pri porovnaní ubytovaných návštevníkov zo Slovenska s poradím virtuálneho obrazu sú badatel'né evidentné rozdiely v prospech prihraničných krajov. Zlínsky a Moravskosliezsky patria na druhé, resp. tretie miesto v poradí ubytovaných návštevníkov v HUZ zo Slovenska, no virtuálny obraz ich radí až na desiate, resp. deviate miesto. Poloha, blízkost' a dostupnost' od hraníc Slovenska je jednoznačne významný faktor stimulujúci návštevnost' zo strany slovenských turistov. Ukázalo sa, že poradie krajov zostavené na základe virtuálneho obrazu je ovel'a bližšie poradiu celkovej návštevnosti všetkých ubytovaných v HUZ. To potvrdzuje aj predošlé konštatovanie o plánovanom a reálnom počte prenocovaní, kde bližšie realite bolo porovnanie počtu prenocovaní s domáci návštevníkmi.

Jednoznačný lídrom v atraktivite je Juhočeský kraj. Nielen podielom v plánovaných itinerároch, ale aj s vel'mi dobrou rozmanitost'ou a viditel'nost'ou turistických ciel'ov (spolu štrnást' lokalít). Taktiež Juhočeský kraj zaznamenal spolu až jedenást' plánovaných lokalít. Na druhej strane viaceré kraje nedokázali oslovit' respondentov širšou ponukou a dominovalo jedno centrum: Ostrava v Moravskosliezskom kraji, Olomouc v Olomouckom kraji, Plzeň v Plzenskom kraji či Karlove Vary $\mathrm{v}$ rovnomennom kraji, ktoré sa ako mesto vôbec najviac objavovali v jednotlivých plánovaných itinerároch. V realizovanom výskume najhoršie obstál Liberecký kraj. V poradí reálnej návštevnosti podl’a HUZ v roku 2017 bol Liberecký kraj na šiestom mieste, no v poradí virtuálneho obrazu obsadil až posledné miesto s tromi individuálnymi návštevami, išlo konkrétne o mesto Liberec, CHKO Český ráj a CHKO 
Jizerské hory. Taktiež reálna návštevnost' slovenských turistov v roku 2017 bola na úrovni krajov najnižšia. Atraktívne miesta ako Máchovo jazero, Kokořínsko či Harrachov v Krkonošiach si určite zaslúžia lepšiu marketingovú podporu zo strany regiónov, ked’že povedomie u potenciálnych návštevníkov zo Slovenska o týchto lokalitách je minimálne.

Tab. 1. Poradie v návštevnosti krajov

\begin{tabular}{lccc}
\hline Kraj & $\begin{array}{c}\text { Návštevníci v HUZ } \\
\text { zo Slovenska (2017) }\end{array}$ & $\begin{array}{c}\text { Návštevníci v HUZ } \\
\text { celkom (2017) }\end{array}$ & $\begin{array}{c}\text { Potenciálni návštevníci } \\
\text { výskum }(2016)\end{array}$ \\
\hline hl. m. Praha* & - & - & - \\
Juhomoravský & 1 & 1 & 1 \\
Zlínsky & 2 & 9 & 10 \\
Moravskosliezsky & 3 & 7 & 9 \\
Stredočeský & 4 & 5 & 5 \\
Juhočeský & 5 & 2 & 2 \\
Olomoucký & 6 & 10 & 8 \\
Královohradecký & 7 & 3 & 4 \\
Vysočina & 8 & 12 & 11 \\
Pardubický & 9 & 13 & 12 \\
Karlovarský & 10 & 4 & 3 \\
Plzenský & 11 & 8 & 6 \\
Ústecký & 12 & 11 & 7 \\
Liberecký & 13 & 6 & 13 \\
\hline
\end{tabular}

* Praha - bez hodnotenia

Posledným sledovaným prvkom výskumu boli informačné zdroje. Respondenti pri tvorbe svojich itinerárov čerpali hlavne z českej verzie otvorenej encyklopédie Wikipedia.cz. Tu je potrebné konštatovat', že táto platforma by mala byt' zaujímavá pre všetky regionálne agentúry rozvíjajúce cestovný ruch. Celosvetovo sa zarad'uje medzi internetové stránky s najvyššou návštevnost'ou. V Česku aj na Slovensku dosahuje až dvojtretinový podiel návštevnost' vyhl'adávanie cez tzv. ,search engines“, napríklad cez google search (Alexa Internet 2018a, 2018b).

$\mathrm{V}$ realizovanom výskume patrili k navštevovaným zdrojom aj portály periodík s informáciami o turistických lokalitách. K stránkam, odkial' čerpali respondenti informácie, patrí aj štátny portál czechtourism.cz a prepojený portál kudyznudy.cz. Ďalšie internetové stránky využité počas výskumu boli www.treking.cz, www.kct.cz, www.turistika.cz, www.atlasceska.cz a www.vyletnik.cz. Celkom zásadným spôsobom chýbali oficiálne stránky regionálnych organizácií, resp. samospráv, ktoré by mali poskytovat’ informácie pre potencionálnych návštevníkov.

\section{ZÁVER}

Konštatovanie, že Slováci majú najlepší prehl'ad o možných turistických ciel'och v Česku (CzechTourism 2014), nemožno na základe realizovaného výskumu potvrdit', ked’že sa neporovnával s obrazom u potenciálnych návštevníkov z iných krajín. Je však možné tvrdit', že správanie potenciálnych návštevníkov zo Slovenska má na základe analýzy virtuálneho obrazu bližšie k správaniu domácich českých turistov. Počet naplánovaných prenocovaní (3,5 noci) počas letnej sezóny 2017 (výskum realizovaný v septembri 2016) bol takmer totožný s reálnou dížkou 
prenocovaní českých návštevníkov počas júla a augusta 2017 (3,3 noci). Priame zadanie nárazového výskumu preukázalo u slovenských respondentov vyššiu priestorovú atraktívnost' Ceska v porovnaní s reálnou návštevnost'ou Slovákov. Do procesu tvorby obrazu nevstupoval faktor polohy $\mathrm{v}$ zmysle vzdialenosti od domova, ktorý do vel'kej miery ovplyvňuje reálnu návštevnost' hlavne v pohraničných lokalitách. Neexistujúca jazyková bariéra je vel'kou výhodu pri plánovaní individuálnych pobytov a zároveň je aj hlavnou príčinou vzniknutých odlišností medzi obrazom a reálnou návštevnost'ou. Pri vhodne zvolených cielených marketingových aktivitách stimulujúcich obraz Česka a proces rozhodovania o výbere destinácie možno predpokladat' narastajúci záujem zo strany návštevníkov zo Slovenska. Výskum poukázal na to, že organizácie regionálneho manažmentu cestovného ruchu majú viaceré príležitosti na lepšiu distribúciou návštevníkov mimo územia hlavného mesta Prahy. Pri hodnotení obrazu obstál najslabšie na úrovni krajov Liberecký kraj. Viaceré kraje lákali len svojím krajským sídlom. Aktivity na zvyšovanie povedomia o Česku by sa mali zamerat' aj na vidiecku krajinu a organizované kultúrne podujatia, ktoré ostali slabo viditel'né. Samozrejme, percepčný obraz, ktorý vzišiel z výsledkov výskumu, treba chápat' v limitoch daných samotným zadaním. $\mathrm{V}$ prvom rade je ich platnost' obmedzená časovo a $\mathrm{v}$ druhom rade sa viaže na užšiu ciel'ovú skupinu vysokoškolských študentov. Aj na základe štatistických údajov o ubytovaní, či výskumoch realizovaných centrálou cestovného ruchu CzechTourism, je potrebné si stále uvedomovat dominantnú atraktivitu hlavného mesta Prahy a z toho vyplývajúci dosah na cestovný ruch celej krajiny.

Príspevok vznikol za podpory grantu v rámci projektu VEGA 1/0540/16.

\section{LITERATÚRA}

ALEXA INTERNET (2018a). Top sites in Czech Republic, [Online]. Dostupné na: https:// www.alexa.com/topsites/countries/CZ [cit: 23-3-2018].

ALEXA INTERNET (2018b). Top sites in Slovakia, [Online]. Dostupné na: https:// www.alexa.com/topsites/countries/SK. [cit: 23-3-2018].

BALOGLU, S., McCLEARY, K. W. (1999). A model of destination image formation. Annals of Tourism Research, 26, 868-897.

BEERLI, A., MARTÍN, J. D. (2004). Factors influencing destination image. Annals of Tourism Research, 31, 657-681.

CÁKOCI, R. (2008) Metóda AQITI - evaluácia propagácie cestovného ruchu na internete. Geografické informácie, 12, 244-250.

CÁKOCI, R. (2009). Virtuálny obraz regiónu na internete v kontexte rozvoja cestovného ruchu. In Fňukal, M., Frajer, J., Hercik, J., eds. 50 let geografie na Př́rodovédecké fakultě Univerzity Palackého v Olomouci: Sborník príspěvkủ z konference, Olomouc 10.-11. 6. 2009. Olomouc (Př́rodovědecká fakulta UP v Olomouci), CD-ROM, pp. 237245.

CÁKOCI, R. (2015). Obraz regiónu cestovného ruchu: metódy a ich aplikácie. Bratislava (Univerzita Komenského v Bratislave).

CZECHTOURISM (2010). Výzkum zaměrený na motivaci potenciálních zahraničních turistů (Evropa), Ipsos Tambor, záverečná správa z výskumu, [Online]. Dostupné na: http://www.czechtourism.cz/getmedia/5c9dd2bd-43f8-441c-91a66a4fd0a13b0f/13 06 12_evropa_zaverecna_zprava.pdf.aspx [cit: 8-11-2017].

CZECHTOURISM (2014). Monitoring zahraničnich turistů v návaznosti na turistické produkty v geografickém členění - Evropa, záverečná správa, [Online]. Dostupné na: https://www.aldr.cz/doc/monitoring-zahranicnich-navstevniku-ceske-republiky [cit: 8-11-2017]. 
CZECHTOURISM (2017). Př́ijezdový cestovní ruch - rok 2016. Agentúra STEM/MARK, [Online]. Dostupné na: http://www.czechtourism.cz/institut-turismu/marketingovyvyzkum/prijezdovy-cestovni-ruch/ [cit: 8-11-2017].

ČESKÝ STATISTICKÝ ÚŘAD (2018). [Online]. Dostupné na: https://www.czso.cz/csu/ czso/cestovni ruch [cit: 23-3-2018].

DAVIDSON, A. P., YU, Y. (2005). The internet and the occidental tourist: an analysis of Taiwan's tourism websites from the perspective of western tourists. Information Technology \& Tourism, 7, 91-102

ECHTNER, CH., RITCHIE, J. R. B. (2003). The meaning and measurement of destination image. The Journal of Tourism Studies, 14, 37-48

GOODRICH, J. N. (1978). The relationship between preferences for and perceptions of vacation destinations: application of a choice model. Journal of Travel Research, 17(2), 8-13.

GOULD, P., WHITE, R. (1986). Mental maps. London (Routledge).

GOVERS, R., GO, F. M., KUMAR, K. (2007). Virtual destination image. A new measurement approach. Annals of Tourism Research, 34, 977-997.

GREGOROVÁ, B. (2008). Mentálne mapy ako metodický výskumný nástroj mestského cestovného ruchu na priklade Banskej Bystrice. Banská Bystrica (Scienta Iuventa).

HANUSOVÁ, Ž. (2012). Hodnotenie vybraných prvkov mediálneho obrazu Macedónska ako regiónu cestovného ruchu. Bakalárska práca, Univerzita Komenského v Bratislave, Bratislava.

HUNT, J. (1975). Image as a factor in tourism development. Journal of Travel Research, 13 (3), $1-17$.

CHOI, S., LEHTO, X. Y., MORRISON, A. M. (2007). Destination image representation on the web: content analysis of Macau travel related websites. Tourism Management, 28, 118-129.

CHON, K. (1990). The role of destination image in tourism: a review and discussion. The Tourist Review, 45(2), 2-9.

JAHNÁTKOVÁ, L. (2015). Cestovný ruch Juhomoravského kraja a hodnotenie jeho obrazu vo vnímaní potenciálnych návštevníkov zo Slovenska. Bakalárska práca, Univerzita Komenského v Bratislave, Bratislava.

JAMBOROVÁ, K. (2018). Cestovný ruch Karlovarského kraja a jeho aktuálny obraz z pohl'adu slovenského návštevníka. Bakalárska práca, Univerzita Komenského v Bratislave, Bratislava.

KONRÁDOVÁ, N. (2013). Hodnotenie vybraných prvkov obrazu Baleárskych ostrovov ako regiónu cestovného ruchu. Bakalárska práca, Univerzita Komenského v Bratislave, Bratislava.

KOZAK, N. (2007). External information search behaviour of visitors to Turkey. International Journal of Hospitality \& Tourism Administration, 8(3), 17-33.

LAW, R., QI, S., BUHALIS, D. (2010). Progress in tourism management: a review of website evaluation in tourism research. Tourism Management, 31, 297-313.

LEISEN, B. (2001). Image segmentation: the case of a tourism destination. Journal of Services Marketing, 15, 49-66.

LYNCH, K. (1960). The image of the city. Cambridge (MIT Press).

MARTINÉZ-GARCIA, E., RAYA, J. M. (2008). Length of stay for low cost tourism. Tourism Management, 29, 1064-1075.

MAYO, E. J., JARVIS, L. P. (1981), The psychology of leisure travel. Boston (CBI).

MINISTERSTVO PRO MÍSTNÍ ROZVOJ ČR (2018). [Online]. Dostupné na: http:// www.mmr.cz/getmedia/a13d24a4-fe61-4a02-a30d-ab0b6738d701/12-TSA-hlavniukazatele-NH-a-CR 1.pdf [cit: 8-11-2017].

OŤAHEL, J., IRA, V., ḦLAVATÁ, Z., PAZUR, R. (2018). Visibility and perception analysis of city monuments: the case of Bratislava city centre (Slovakia). Moravian Geografiphical Reports, 26, 55-68.

PAN, B., LI, X. (2011). The long tail of destination image and online marketing. Annals of Tourism Research, 38, 132-152. 
PIKE, S. (2002). Destination image analysis - a review of 142 papers from 1973 to 2000. Tourism Management, 23, 541-549.

PIKE, S. (2009). Destination brand positions of a competitive set of near-home destinations. Tourism Management, 30, 857-866.

ŠIFTA, M., CHROMÝ, P. (2014). Symboly a identita regionu: analýza vnímaní přírodních symbolů oblastí s intenzivně přeměněnou krajinou v Česku. Geografický časopis, 66, 401-415.

VYSTOUPIL, J., KUNC, J., HOLEŠINSKÁ, A., MARYÁŠ, J., VITURKA, M., SEIDENGLANZ, D., ŠAUER, M., TONEV, P. (2006). Atlas cestovního ruchu České republiky. Praha (Ministerstvo pro místní rozvoj CR).

VYSTOUPIL, J., ŠAUER, M., HOLEŠINSKÁ, A., KUNC, J., TONEV, P., SEIDENGLANZ, D. (2011). Geografie cestovního ruchu České republiky. Plzeň (Aleš Čeňek).

\author{
Rastislav Cákoci, Ladislav Tol máč $i$
}

\title{
CURRENT DESTINATION IMAGE OF CZECHIA CREATED BY UNIVERSITY STUDENTS - POTENTIAL VISITORS FROM SLOVAKIA
}

The paper confronts the statistically accessible spatial distribution of visitors from Slovakia with the empirical studies of the image of the planned stay in the Czech Republic and analyses the deformations between the real situation and the image created by planned stays according to the research.

The previous undertaken research had no detailed spatial aspects of the analysed problem. It means precisely the analysis of the spatial preferences of tourist attractions that results from short-term research of the AQITI method. Research timing provided the possibility of confronting the length of the planned stay with the real values of the accommodated visitors. From this perspective, the resulting image from the typological point of view of the AQITI method is ranked positively over-sized. This type of virtual image has a distinctly attractive presentation on the Internet and excellent information availability. It may, however, carry some risk of disappointing a visitor during a real visit in the case of unfulfilled expectations.

The direct assignment of the impact research proved to the Slovak respondent the higher spatial attractiveness of the Czech Republic compared to the real Slovak visitors. The positioning factor in terms of distance from home does not alter the image making process. What mostly affects it, is the real traffic, especially in the border areas. A non-existent language barrier is a great advantage in the planning of the individual stays of Slovaks in Czechia, and at the same time it is the main cause of the differences between image and real visits. In the case of suitably selected targeted marketing activities stimulating the image of Czechia and the decision-making process of destination selection, one can expect a growing interest from visitors from Slovakia. Research has highlighted a number of opportunities for regional tourism management organizations to better distribute visitors outside the capital city of Prague. In the evaluation picture, the weakest of all Czech regions is the Liberec region. In several regions is really attractive only their regional seat. Activities to raise awareness about Czechia should also focus on countryside and organized cultural events that remain poorly visited. Of course, the perceptual image that emerged from the research results must be understood within the limits that are based on the assignment itself. In the first place, its validity is limited in time, and in the second place it is linked to a narrower target group of university students. Even on the basis of statistical data on accommodation or research carried out by the Czech Tourism Authority, it is necessary to keep in mind the dominant attractiveness of the capital city of Prague and the resulting impact on the tourism of the whole country. 